\title{
Healthcare of Workers in the Vitkovice Ironworks as Part of the Workload of Social Workers in Industrial Companies in 1954
}

M. Spilackova (Marie Spilackova)

University of Ostrava in the Czech, Faculty of Social Studies, CZ

\section{E-mail address:}

marie.spilackova@osu.cz

\section{Reprint address:}

Marie Spilackova

University of Ostrava in the Czech, Faculty of Social Studies

Fr. Sramka 3

70900 Ostrava - Marianske hory

$\mathrm{CZ}$

Source: Clinical Social Work and Health Intervention

Pages: $71-76$

Volume: 9

Issue: 1

\section{Reviewers:}

Andrea Shahum

University of North Carolina at Chapel Hill School of Medicine, USA

Vlastimil Kozon

Allgemeines Krankenhaus - Medizinischer Universitätscampus, Vienna, AT

\section{Key words:}

Social Work. Companies. History. Health of Workers. Vitkovice Ironworks. Bohemia and Moravia.

\section{Publisher:}

International Society of Applied Preventive Medicine i-gap

CSWHI 2018; 9(1): 71 - 76; DOI 10.22359/cswhi_9_1_11 @ 2018 Clinical Social Work and Health Intervention

\section{Abstract:}

Objective: This paper aims to describe the healthcare of workers, including institutions and their provided Social Services, to define the role of a Social Worker and to identify the methods of Social Work used in the company Slobodníková Vitkovice Ironworks in the former Czechoslovakia. 
Design: Historical research.

Participants: Archival materials of Vitkovice Ironworks and available relevant literary sources on the topic covering the period between 1876 - 1954.

Methods: A combination of research methods: (1) Hermeneutic-classificatory Content Analysis according to Plichtová (1996), (2) Thematic Analysis according to Catherine Kohler Riessman (2008) following Michael Foucault's Genealogical Method.

Results: The workers' health at Vitkovice Ironworks was one of the priority areas of the Social Care System in the company. Since 1945 the position of Social Workers has existed under the Social Care Department and their job description also included addressing the health issues of the workers.

Conclusion: The result is the discovery, in the considered time, that the health care of workers was an integral part of the corporate social policy of the Vitkovice Ironworks, in which professionally educated Social Workers participated with their specific methods.

\section{Introduction}

Vitkovice Ironworks have been described as one of the largest metallurgical enterprises in the Austro-Hungarian Empire, which earned its fame for its social activities geared towards supporting their employees. Jemelka et al. (2015) expands the description of the ironworks so that they are viewed as an iconic example of a European factory town. In historical literature, pithy development of social policy dates back to the assumption of the ironworks by a new director P. Kupelwieser in 1876. However, analysis of Social Work in this company is missing from the professional literature. Well-developed professional Social Work was identified in the company after World War II, yet because of the overwhelming amount of archival material, the analysis has been limited to the year 1954. Healthcare for workers was implementation of professional Social Work.

\section{Research Methodology}

In accordance with its hermeneutic background, our methodology is based on historic research. The selected research design corresponds to the concept of social and economic history, exploring the transformation of social institutions, communities and structures. Research methods include a hermeneutic- classificatory content analysis according to Plichtová (1996) and a thematic analysis according to Riessman (2008), which is applied to the gathered findings.

\section{Definition of Social Work in Bohemia and Moravia}

Social Work in the Czech historical context is perceived mainly as a professional activity carried out based on specific methods in various areas of Social Careand with theoretical support of its own findings as well as findings provided by other disciplines. At the Congress of Social and Health Work in the Czechoslovak Republic in 1928, Bláha defined Social Work as a specialized activity that seeks to remove or compensate social problems (Klíma, 1931). Social Work has also found its application in the care of 
workers in factories in the form of general measures and organization of Social Care Services such as provision of canteen meals, healthcare and other services. The topic of Social Services in the industry emerged in 1928 as an official professional section of the International Conference in Paris where there were, amidst the keynote speakers, Marie Krakesova, Helena Radlinska and others (Kotek, 1928).

\section{Introduction to the History of the Vitkovice Ironworks and their Social Care System}

The Social Care System for the employees of the Vitkovice Ironworks was considered a structured form of assistance under the Austro-Hungarian Empire. Activities with a social focus included the construction of hospitals and healthcare facilities, day nurseries, kindergartens, orphanages and retirement homes, meal canteens and cafeterias and others, as well as the construction of the so-called Nove Vitkovice (New Vitkovice). Thanks to its social program, in many ways the ironworks became a pioneering company in the field of advanced business methods not only in the Czech lands, but also in the Habsburg Empire (Sevecek, 2009). The Ironworks needed a stable base for its workers, therefore it cared for the social, health and educational conditions of its employees and their family members. Kupelwieser understood the link between the general well-being of his employees and their families and the quality of the workforce, reflected in the end results of the company (Matej, Korbelarova, Leva, 1992). At the beginning of the 20th Century, the Social CareSystem was created that contained a number of benefits which it provided to the ironworks employees. Social benefits had a positive effect on the living standard of workers, encouraging their involvement in their work for the company.

\section{Institutions and Provided Social Services}

Since 1919, the management of the ironworks had regularly submitted a summary report - with statistics on health and social facilities set up by individual plants in favor of the workers - to the District Care for Youth in Moravska Ostrava. The report included a description and statistical data from the following facilities: Charitable trust for raising funds for the VHHT orphanage; Shelter for convalescents; Counseling Services for patients with skin and sexually-transmitted diseases; Counseling Services for infants; Counselling services for patients with tuberculosis, Children's homes, a Charitable trust for an old people's home founded by Vilem Gutmann; as well as Homes for apprentices (Archive of VHHT 11, inv. no. 1610, ref. no. 302). The Social Care System was gradually expanding through the establishment of some new Social Care Facilities. Great attention was paid to their employees' health. Despite the positively described social policy implemented by Vitkovice Ironworks, the workers were often out sick or suffered from work injuries. The company hospital had been functioning since 1840. Both the high accident and sickness rate among steelworkers forced the management of the company to establish the Knappschaftspital (a hospital for ill workers) in one of the residential buildings. This hospital was the first in-patient facility, not only in the Ostrava region, but also across the Austrian Empire (Matejcek, Vytiska, 1978). In the period between WWI and WWII, the hospital was equipped with the latest amenities and a well-organized rescue service. At the same time, a hospital for patients with contagious diseases; a shelter for convalescents; a resort for summer and winter holidays in the Beskydy mountains were set up for office workers. Spacious workers' washrooms in all plants; office worker spa with a large indoor swimming pool as well as a summer swimming pool also served for health 
purposes. Sports were possible in a large sports house with two outdoor fields to play football; several tennis courts; and a track for cyclists (Archive of VHHT 11, inv. no. 1610, ref. no. 302).

\section{Application of Social Work in the Healthcare of Workers}

Based on primary documents, the Social Worker position existed and was established in Vitkovice Ironworks in 1945 in connection with the defined content of Social Careand the job description of a Social Worker. The terms - Social Worker and Social and Health Worker - are used as synonyms and vary in the texts, which corresponds to the concept of Social Work in the designated area. The Director Dr. Herain was assigned the implementation of Social Policy in 1937, being put in charge of the following facilities: an insurance company for sick workers; a retirement fund institution; a care providing institution; a company hospital; the professional preparation of apprentices. Inspector Langfort, with six other employees, was in charge of the Department of Social Care. After 1945, the name of the Social Care Department continued to change in quick succession, as well as its inclusion in the trade unions of the ironworks. The Department had gone through various appellations, such as the Social Care Department; Social Group; Personnel Care Department; Social Section up to the final designation Social Department in the Employment Department. In 1949, the ironworks had a Functional Economic and Social Department whose activities were divided into individual departments which also included the Healthcare Sector (a company hospital; 8 company outpatient clinics; 4 health rescue stations; a Social Care Department (the management of charitable trusts and foundations; care for employees and their families; a day nursery and a home with a kindergarten for the children of mothers employed in the national enterprise; recreational care company; Social Care and Occupational Hygiene Charity Services; social research as well as statistics and planning. The Social Care Department managed and administered various funds of employees, foundations and a network of company Social Workers in different workplaces of the enterprise (Archive of Vitkovice 1946-1954, inv. no. 898, ref. no. 153).

\section{Social Work Methods Used at the}

\section{Vitkovice Ironworks}

Social Workers were mainly engaged in individual casework, however, they also delivered educational lectures in the social and medical field and promoted them through radio broadcasts and the press. The topics of the lectures included general hygiene, pregnancy, childcare, and sexually transmitted diseases. Social Workers tried to persuade, especially young workers, to attend cooking classes, sewing and educational courses. Archive materials prove further professional activities as part of the Social Worker's job description - the social investigation of families - the so-called bureaucratic intervention and promotion (Archive of Vitkovice 1946-1954, inv. no. 1070, ref. no. 167). Vocational schools were also those that responded to the need for professionally trained Social Workers to work in factories. In 1947, under the Vocational School for Female Occupations in Ostrava, the first grade of a future four-year Social and Health Care School and the 2nd Grade of the School for Training of Social Workers were established. The report of final graduation examinations shows that the female students completed their 2nd Year of Mandatory Practice at the Vitkovice Ironworks in the area of Factory Care. Thematically selected graduation questions were "Organisation of Social Policy in the Nationalized 
Enterprises," "Care for Workers in the People's Democracy" or "Housing Care and Catering of Workers" (Archive of Ostrava, Higher Medical School in Vitkovice, file no. 6, inv. no. 125).

\section{Conclusion}

The nature of metallurgical production required continuous attendance by workers without any interruption. Suspension of production (burnout of the furnaces) would mean great financial losses for the owners of the ironworks. Therefore it was necessary to keep workers on their jobs. One of the options was social benefits, such as providing housing, stable income, healthcare and education for their children. In its early days, assistance provided by the Vitkovice Ironworks was focused on support in case of the incapacity to work due to sickness or injury. For this purpose, a fraternal fund, which consisted of a treasury for the sick workers as well as a care providing facility, was founded. Unfortunately, the fraternal fund ceased to exist in 1895. After that, as its successor, a health insurance company replaced it, referring to the legislative requirement and the general care providing institution that managed several social funds. A retirement fund institution had already started in the 1840s. Financial security for old age was also linked to the worker's qualification. Only the guards, foremen and lower rank officials were granted a pension from the retirement fund. A retirement treasury was founded for other employees. An integral part of social activities were those made by Healthcare Workers, which included provision of meals, construction of a hospital, professional counseling centers and a shelter for convalescents. In 1927, the ironworks management set up a workshop for employees who, due to injury in the ironworks, had become "disabled." After WWII, the workshops were used to retrain healthy employees for new jobs, which were more in demand. Today, we would call this a form of retraining. In the period in which Paul Kupelwieser served in the position of the Director General, Healthcare focused on the functioning and development of a hospital; in the area of childcare, emphasis was placed on the establishment and functioning of a children's shelter, an orphanage and a day nursery, as well as the establishment of primary schools. Meal catering was centered on the opening of a market place, grocery shops and canteens directly in the plant. After 1900, Healthcare also began to expand into other areas. Specific counseling centers were opened, and employees, following their illnesses, were allowed to remain in convalescence. Institutionalized elderly care was established. Education expanded to the apprenticeship level, and employees were served meals in canteens. After the retirement of Director Kupelwieser, Social Care was expanded to include care for the elderly, people with disabilities, care for apprentices; the supply of Healthcare Services also expanded, etc. Besides the above-mentioned activities of a social nature, which were maintained even after 1945, the actual Social Work activities of the Social Care Department, functions and role of Social Workers, including the possibility of their training and involvement in Vitkovice Ironworks in social research, continue to newly emerge. The ironworks ran several facilities, which, amongst others, included several kindergartens and a shelter for children. Archive material from 1937 states that the kindergartens and the shelter were supervised by two inspectors. In 1945, that is eight years later, the documents are already more specific about this topic. The shelter was managed by a company Social Worker who supervised socio-medical aspects of the company-run nurseries. From this it can be concluded - provided that in 1937 there was already a Social Care 
Department in place - that the aforementioned Inspectors could be Social Workers. It was not an inspection in the strict sense, but the performance of Social Work. The utilized methods of Social Work particularly include individual casework in the form of counseling and also contemporary literary sources mention the method of official intervention in a family. Unfortunately, this method is not further specified. In addition, Social Workers used to deliver educational lectures in the social and medical field and promoted Social Work through radio broadcasts and the press.

\section{References}

1. ARCHIVE OF OSTRAVA, Higher Medical School in Vitkovice, file no. 6, inv. no. 125.

2. ARCHIVE OF VHHT 11, inv. no. 1610, ref. no. 302 .

3. ARCHIVE OF VITKOVICE, Vitkovice 1946-1954, inv. no. 1070, ref. no. 167.

4. ARCHIVE OF VITKOVICE 1946-1954, inv. no. 898 , ref. no. 153 .
5. JEMELKA M et al. (2015) (ed.) Ostrava Workers Colony III: Race Colony of Vitkovice Ironworks and Other Industrial Enterprises. Ostrava: University of Ostrava, ISBN 978-80-7464-754-3.

6. KLIMA JV (1931) Social and healthcare and their relations to pedagogy. Pedagogical perspectives year. XLI. s.30-34.

7. KOTEK J (1928) International congresses organized in the framework of the "Fourteen Days of International Social Welfare” in Paris in 1928. Social Revue, year. IX. s. 368-376.

8. MATEJ M, KORBELAROVA I, LEVA P (1992) New Vitkovice (1876-1914). Ostrava: Memorial Institute, ISBN 80-85034-07-7.

9. MATEJCEK J, VYTISKA J (1978) Vitkovice. Praha: Work.

10. PLICHTOVA J (1996) Content analysis and its use in psychology. Cz. Psychology, vol. 4, 40/1996. p. 304-314.

11. RIESSMAN KC (2008) Narrative Methods for the Human Sciences. Los Angeles: Sage.

12. SEVECEK O (2009) The birth of Bata's industrial metropolis. Ostrava: University of Ostrava. ISBN 978-80-7368-678-9. 